\title{
JURNAL BIOEDUKATIKA
}

http://journal.uad.ac.id/index.php/BIOEDUKATIKA 2338-6630 (Print) | 2541-5646 (Online)

\section{Portfolio assessment with dimension of learning: an approach on the mastery of concept \\ Check for updates}

\author{
Nurkhairo Hidayati a, 1 , Tengku Idris ${ }^{\text {a, }}{ }^{2}{ }^{*}$, Peny Husna Handayani b, 3 , Fitri Arsih c, 4 \\ a Biology education department, Faculty of Teacher Training and Education, Universitas Islam Riau, \\ Riau, Indonesia \\ ${ }^{\mathrm{b}}$ Early childhood education department, Faculty of Science Education, Universitas Negeri Medan, \\ Medan, Indonesia \\ 'Biology department, Faculty of Math and Science, Universitas Negeri Padang, Padang, Indonesia
}

${ }^{1}$ khairobio@edu.uir.ac.id; ${ }^{2}$ idrisbio@edu.uir.ac.id *; ${ }^{3}$ peny@unimed.ac.id; ${ }^{4}$ fitribio@fmipa.unp.ac.id

* Corresponding author

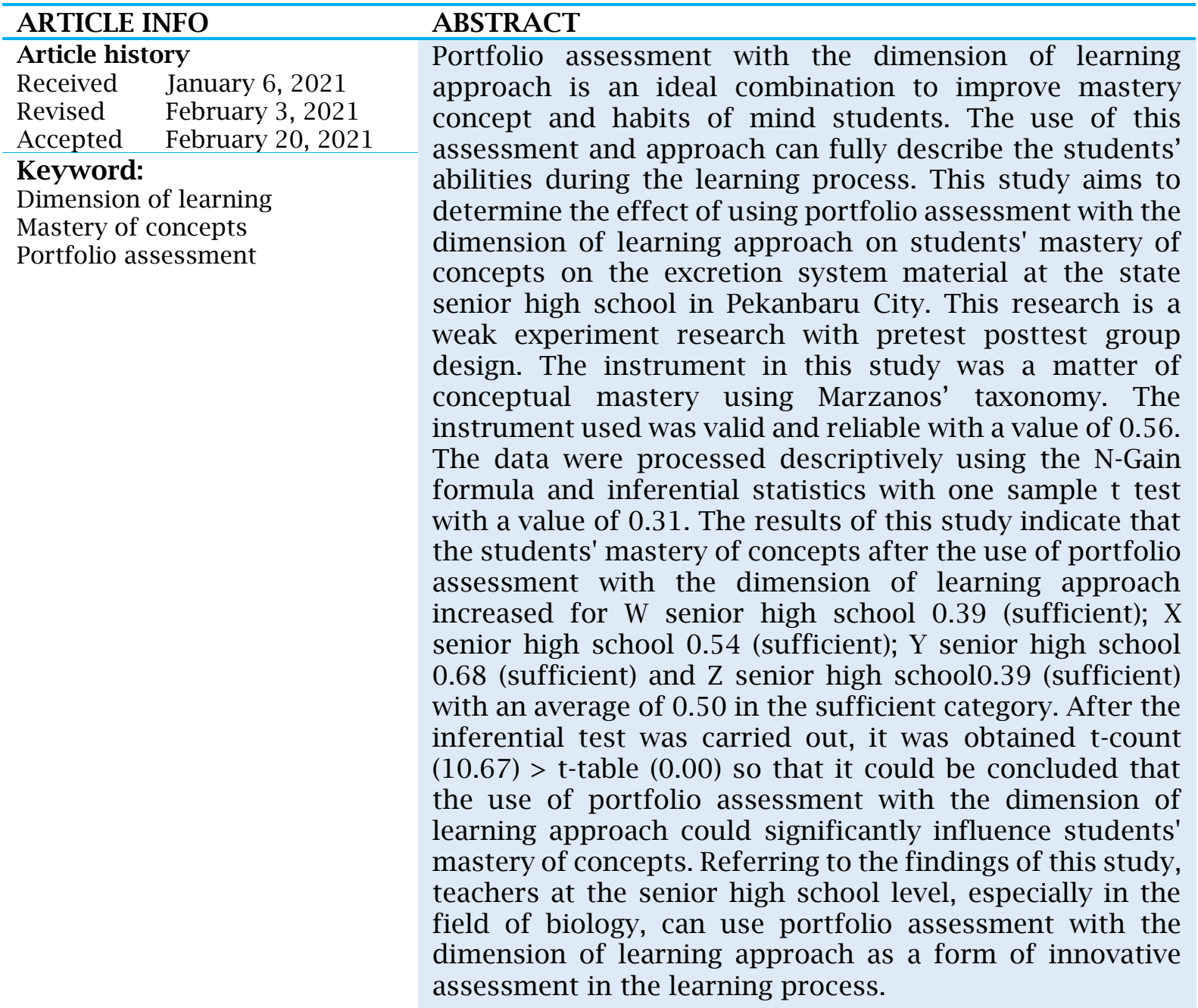

This is an open access article under the CC-BY-SA license. 


\section{Introduction}

The learning process involves interaction between educators and students to achieve certain goals. This process needs to be designed in such a way and implemented properly so that learning objectives can be achieved. However, it is often found that students who are in the same teaching group can reach different understandings. That is why assessment is a central process in effective teaching. Only through the assessment can we find out whether a certain sequence of learning activities has achieved the desired learning goals (Holmes, 2002; Wiliam, 2011) and prove the extent to which students' abilities and improve these abilities (Joshi et al., 2015).

The term assessment was originally used to describe the process of evaluating the effectiveness of a sequence of teaching activities when the activity is completed. Actions that guide the learning process before the end of a sequence of activities are generally not considered a type of assessment (Wiliam, 2011). Currently, assessment refers to all activities carried out by teachers and students in assessing themselves. This process can provide information that is used as feedback to modify teaching and learning activities (Black \& Wiliam, 2010). Another definition of assessment was also expressed by Cowie and Bell (1999), namely the process used by teachers and students to recognize and respond to student learning that aims to improve learning. Assessment is carried out during the teaching process for the purpose of improving teaching or learning (Amua-Sekyi, 2016; Shepard, 2005) by using instruments and processes to gather evidence about student learning (Van der Kleij et al., 2015).

Starting from the various previous definitions, it seems that there are two very important features in designing assessments that will support learning. The first is evidence that is generated and can be followed up instructional (Wiliam, 2011). The evidence referred to here is more than just information about the existence of a gap between current and desired performance. Evidence should also provide information on what types of teaching activities are likely to result in improved performance. The second requirement is that students are involved in action to improve learning by reflecting on various ways to advance their own learning (Wiliam, 2011). Educators often measure student success by only looking at the student's ability to reveal what they have learned (note learning), without paying attention to the ongoing process (Joshi et al., 2015). Although this test can identify students who are less knowledgeable, this type of test cannot identify why students are not proficient. Tests are also not closely related enough to classroom teaching and curriculum to identify what misconceptions students have or information that could help students (Trumbull \& Lash, 2013).

Several research results in Indonesia show that educators make more assessments based solely on the results of tests carried out by students regardless of the process that takes place during learning (Retnawati et al., 2016; Zulfikar, 2018) and one of the causes of this phenomenon is the difficulty of teachers in designing and implementing authentic assessments (Rizavega, 2018). Other studies have shown that the types of assessment that are often used by teachers in daily teaching practice in secondary education are: (a) paper and pencil tests, (b) asking questions, (c) class conversations, (d) homework assignments, and (e) student observations (Kippers et al., 2018). Joshi et al. (2015) in their writing explained that the assessment system still focuses on the type of summative assessment carried out at the end of learning so that the process carried out during the learning period has not been paid attention.

All learning activities become more meaningful if all processes are monitored and assessed fairly. This process can provide feedback for students and teachers in improving learning. Good feedback practices are not only about providing accessible information but also facilitating students to be able to evaluate the progress of the processes they have carried out so that students can strive to improve learning. This is also related to providing good information to teachers through the assessment process carried out (AmuaSekyi, 2016). Therefore, ideally teaching and learning activities need to be evaluated by conducting process assessments. The assessment process uses continuous assessment and is not limited to tests (Frohbeiter et al., 2011) but uses techniques that reveal how students understand certain concepts (Supovitz, 
2012). Assessment of the learning process can be done using alternative assessments, one of which is portfolio assessment (Birgin \& Adnan, 2007; Mhlauli \& Kgosidialwa, 2016; Mogonea, 2015).

Portfolio assessment is one of classbased assessments of a systematic and organized set of student work taken during the learning process over a period of time, used by teachers and students to monitor student progress or progress in one or more areas (Paulson et al., 1991) through analyzing, synthesizing, producing, creating and interacting with other people. All evidence of student activity in portfolio assessment needs to be collected continuously according to predetermined criteria to show student effort, progress, and achievement over a certain period of time (Barton \& Collins, 1997). The element of reflection is an important part of portfolio assessment because it can improve students' thinking skills and understand more deeply a subject (Paulson et al., 1991).

Portfolio assessment is very well applied in the learning process at all levels of education, from school to university level (Ling, 2016) because this assessment has several advantages such as (1) emphasizing the assessment of the process of changing student abilities, (2) enabling assessment is more complex than traditional assessments, (3) allows teachers to assess students based on the characteristics, needs and strengths of each student, (4) allows students to assess themselves (self-assessment) and (5) can describe the strengths and weaknesses students, can also monitor student progress. Mokhtaria (2015) adds that portfolio assessment also has good accountability and describes the learning process authentically.

Several studies have provided information that portfolio assessment has a significant effect on learning outcomes (Cakani et al., 2010) both in science subjects (Cakani et al., 2010; Haruna et al., 2018; Tawiland \& Amin, 2013) as well as in language and arts subjects (Artini et al., 2014; Ling, 2016; Sulistyo et al., 2020). Involving students in collecting various tasks in portfolio assessments can monitor the development of each student so that in the end it improves student learning abilities (Sahu et al., 2008) including generic science skills (Ramlawati et al., 2014). In addition, portfolio assessment also offers a deep and student-centered learning process to improve student learning outcomes (Ring \& Ramirez, 2012), social and academic skills (Mhlauli \& Kgosidialwa, 2016). In addition to having advantages, portfolio assessment also has disadvantages, including requiring more time than the usual teacher assessments because there is feedback on assigned assignments, causing boredom in students because the tasks they are doing must be repaired (Surapranata \& Hatta, 2006), no have certain standards so they are considered less reliable and sometimes require quite high costs (Mokhtaria, 2015).

The learning process is not only determined by the assessment, but what is no less important is the approach used during the learning process. The learning approach influences the procedures and assessment approaches used (Fourie \& Van Niekerk, 2001). One learning approach that can support the learning process is the dimension of learning approach. Dimension of learning was developed by Marzano (1992) with 4 stages, namely attitude and perceptions', acquiring and integrating knowledge, extending and refining knowledge, using knowledge meaningfully and habits of mind. The stages in the dimension of learning are not isolated from one another. Each stage describes a different cognitive process and all need the attention of the teacher during the teaching and learning process. According to Marzano (1992), the most important step is to change students' attitudes and perceptions of learning. If the teacher is successful in doing this, whatever learning objectives are expected to be achieved. The stages contained in the dimension of learning approach correspond to the purpose of portfolio assessment, which is to record all the processes that students go through during learning and not only on assessments that focus on recalling information. Another positive impact of the dimension of learning approach is that it affects students' mastery of concepts, thinking skills and attitudes in science subjects (Abedl \& Alrababah, 2017; Javed, 2012). The research results of Abdulrab and SridharSingh (2012) show that the dimension of learning approach can improve student achievement in the field of science because this approach emphasizes active learning. 
Referring to the explanation described in this section, this research aims to improve conceptual mastery among high school students in Pekanbaru City, Indonesia using a portfolio assessment with the dimension of learning approach. The research hypothesis states that using portfolio assessment with dimension of learning approach has a significant influence on students' mastery of concepts.

\section{Method}

The research design used was The One-Group Pretest-Posttest design. The application of the use of portfolio assessment is applied to four experimental class. The measurement of students' habits of mind and concept mastery was carried out through pretest and posttest. The design in this study does not have a control class because it is very difficult to find a strategy that is compatible with portfolio assessment. In addition, research with the application of portfolio assessment requires more time and effort so that the procurement of control classes will make the application of the assessment not optimal.

During the research implementation, we used a sample of 140 students. Determination of the sample using purposive sampling technique by taking into account the normality and homogeneity of the sample. These students come from four different state senior high schools with the following details; W state senior high school (37 people), $X$ state senior high school (33 people), Y state senior high school (37 people) and Z state senior high school (33 people).

The instrument in the form of a test question in the form of an essay was used to collect data on students' mastery of concepts after implementing a portfolio assessment using the dimension of learning approach. The essay test was used as a current evaluation test in each experimental class. The concepts that are used as standards in the preparation of this essay test consist of excretory structures and organs, physiological processes, excretory organ abnormalities and the excretory system in animals. The concept of mastery of the concept was validated in a construct by evaluating experts and then tested empirically using the ANATES V.4.0.9 program. From the validity test, it was obtained 20 valid questions with the reliability of 0.61 in the high category. After being validated, 20 questions were obtained consisting of 5 questions for the concept of structure and excretory organs, 9 questions for the concept of physiological processes, 4 questions for excretory organ disorders and 2 questions for the concept of excretory system in animals. In addition to the test instrument, a questionnaire was also used in this study to determine student responses to learning. The indicators of student responses to learning are: the benefits of written feedback and self-assessment as well as tracing student responses to the learning process scenario.

The data from the research results were processed using descriptive statistics and inferential statistics. For concept mastery data and student responses to learning are processed descriptively using the percentage formula (Sugiyono, 2015).

$$
\mathrm{MC}=\frac{\mathrm{As}}{\mathrm{Ms}} x 100 \%
$$

Information:

$\begin{array}{ll}\text { MC } & \text { : Mastery of concepts } \\ \text { As } & \text { : Acquisition score } \\ \text { Ms } & \text { : Maximum score }\end{array}$

The percentage yield categories are described as follows, namely $86-100 \%$ Very Good, 76 - 85\% Good, 60 - 75\% Pretty Good, 55 - 59\% Poor and < 55\% Very Poor category. The increase in students' mastery of concepts after learning was analyzed using the N-Gain formula (Hake, 1999).

NGain $=\frac{\text { postest score }- \text { pretest score }}{\text { maximum score-pretest score }}$

The results from N-Gain were categorized based on the following ranges, namely $>0.70$ (high), $0.31-0.70$ (moderate) and $<0.30$ (low). To determine the significance of this increase, the one sample t test was used with a value of 0.31 (moderate $\mathrm{N}$-gain range). The test uses a formula one sample t-tests (Sunarto \& Riduwan, 2013).

$t_{\text {count }}=\frac{\bar{x}-\mu_{o}}{\frac{s}{\sqrt{n}}}$.

Information:

$\mathrm{t}_{\text {count }}=$ The scores are computed and show the value of the standard deviation of the $t$ distribution (Table t)

$\bar{x} \quad=$ The average score obtained from the results of data collection.

$\mu_{o} \quad=$ The hypothesized score. 
$\mathrm{s}=$ The sample standard deviation is calculated.

$\mathrm{n} \quad=$ The number of research samples.

$\mathrm{H}_{0}=$ using portfolio assessment with dimension of learning approach have no significant influence on students' mastery of concepts

$\mathrm{H}_{1}$ = using portfolio assessment with dimension of learning approach have significant influence on students' mastery of concepts.

With the test criteria, reject $\mathrm{H}_{0}$ and accept $\mathrm{H}_{1}$ if Asymp. Sig (2-tailed) is less than $0.025(1 / 2 \alpha)$.

\section{Results and Discussion}

The learning process that takes place using portfolio assessment with the dimension of learning approach can improve students' conceptual mastery of the excretion system material. The value of students' mastery of concepts on this material varies from one school to another which is used as the research sample. Students' mastery of concepts in each school can be seen in Figure 1.

Figure 1 describes the mean score of students' masteries of concepts on the excretion system material after the application of the portfolio assessment. This can be seen from the increase in the mastery of concepts between pretest and posttest. At the time of the concept mastery pretest, students were still in the low category with a percentage of 43.08. After being given treatment using portfolio assessment through the dimension of learning approach, the students' mastery of concepts increased to 74.11 with an NGain of 0.55 in the moderate category (Table 1). Portfolio assessment emphasizes the development of students' views on learning providing follow-up material from a task that has been carried out by students so that students are given the opportunity to develop their abilities and in the end this process will improve students' conceptual understanding.

Mastery of concepts is a cognitive ability and is an important aspect of measuring the success of learning, including learning science. According to Maxwell (2004) the characteristics of science learning emphasize a process approach. This approach encourages students to discover facts, build concepts, theories and scientific attitudes. The process of mastering scientific concepts can be successful if students can simplify abstract material to be easier to understand, provide interpretation and can be applied in everyday life (Baumfalk et al., 2019). Mastery of the correct concepts will be able to increase mastery of higher-order thinking such as critical thinking, creative thinking and problem solving (Cherif et al., 2016; Roy, 2016).

Increasing understanding of the concept in this study cannot be separated from the application of the dimension of learning model and portfolio assessment. Mastery of science lesson concepts can be improved with various approaches, learning strategies, learning models and methods (Baumfalk et al., 2019; Wehmeyer et al., 2012) including through the dimension of learning model. The use of the dimension of learning and portfolio assessment in learning is adjusted to the characteristics of the material and students and the applicable curriculum. This is in line with the statement of Hines et al. (2019) that in implementing the approach used in the learning process must be adjusted to the characteristics of the material/concept and students. To determine the effect of portfolios on increasing concept mastery, Table 2 can be used as a reference.

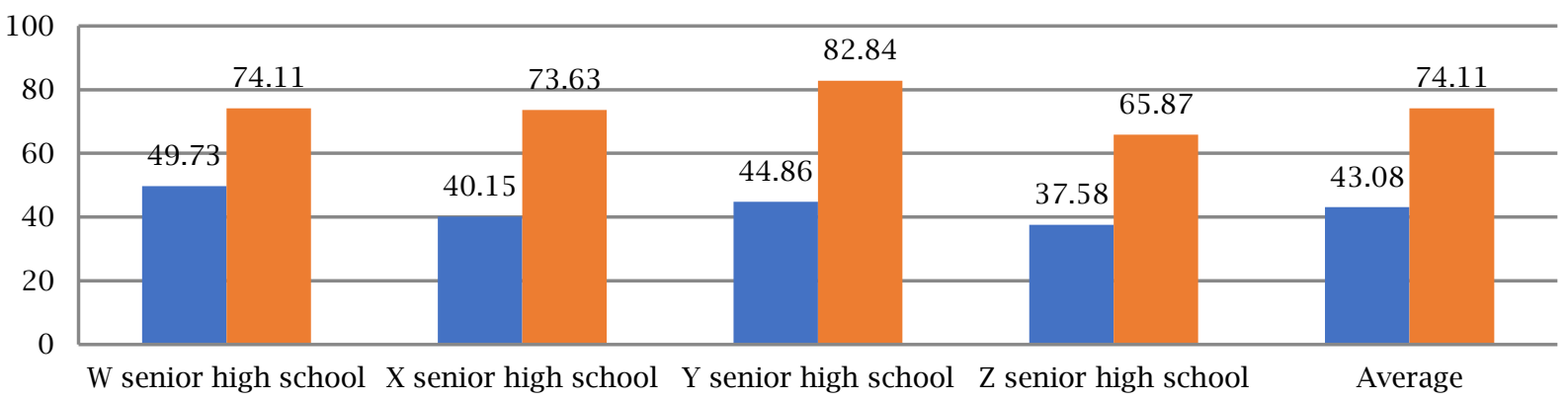

Figure 1.Student concept mastery after portfolio assessment (blue: pretest; orange: posttest) 
Table 1. Result of the N-Gain test for mastery of the concept of state senior high school students in Pekanbaru city

\begin{tabular}{lccccc}
\hline & $\begin{array}{c}\text { W Senior High } \\
\text { School }\end{array}$ & $\begin{array}{c}\text { X Senior High } \\
\text { School }\end{array}$ & $\begin{array}{c}\text { Y Senior High } \\
\text { School }\end{array}$ & $\begin{array}{c}\text { Z Senior High } \\
\text { School }\end{array}$ & Average \\
\hline Pretest & 49.73 & 40.15 & 44.86 & 37.58 & 43.08 \\
Posttest & 74.11 & 73.63 & 82.84 & 65.87 & 74.11 \\
N-Gain & 0.48 & 0.56 & 0.69 & 0.45 & 0.55 \\
\hline
\end{tabular}

Based on Table 2, it can be seen that $\mathrm{H}_{1}$ is accepted, which means that each school using portfolio assessment with dimension of learning approach has a significant influence on students' mastery of concepts with an increase in mastery above 0.31 . The dimension of learning model is used during the process of delivering the material while the portfolio assessment is used when giving assignments to students. The learning model of the dimension of learning which consists of five stages, namely attitude and perceptions, acquiring and integrating knowledge, extending and refining knowledge, using knowledge meaningfully and habits of mind (Marzano, 1992) can facilitate the learning process with dense and complicated material, one of which is excretory system material. In this model, students are invited to think independently by providing multiple stimuli until in the end it is hoped that students will have a habit of thinking (Abedl \& Alrababah, 2017; Rowais, 2019). Based on observations during the study, students showed a positive attitude during learning activities. Many students responded to giving videos at the beginning of the activity. Changes in student perceptions are the key to the initial success of learning.

The use of the dimension of learning model is in line with the use of portfolio assessment. The use of portfolio assessment aims to determine the development of students' conceptual understanding skills during the learning process. Portfolio comes from two words, namely port (short for report) which means report and folio which means full or complete (Olson, 1991; Stiggins, 1994). Meanwhile, according to Rustaman (2010), portfolio comes from the word portfolio which is often referred to as rubrics. In Stiggin (1994) it is said that the meaning of the word portfolio is; "A portfolio is a collection of student work assembled to demonstrate student achievement or improvement", in other words that a portfolio is student work that is assessed on an ongoing basis that shows student learning achievement or improvement (Ling, 2016; Popham, 2000).

Data related to student responses were obtained through giving a questionnaire containing students' opinions on the use of portfolio assessment. The components of portfolio assessment that were explored included the benefits of written feedback and selfassessment. In addition, students' responses to the learning process scenario were also explored. Based on the questionnaire analysis data, a graph can be made as shown in Figure 2.

Figure 2 shows that the overall student response to the portfolio assessment is good, this is reflected in the results of the assessment of the portfolio assessment component in the form of feedback in the good category with a score of $79.26 \%$, selfassessment has a good effect on students' conceptual mastery with a percentage of 83.83\% and the response to the learning scenario was in a good category with a score of $79.93 \%$. In this study, the use of portfolio assessment has advantages and is in accordance with the characteristics of the excretion system material. The excretion system is one of the biological materials that students consider difficult (Doğru \& Özsevgeç, 2018) because the material is dense with complex concepts and processes, is abstract and the process cannot be sensed (Saragih \& Tarigan, 2016).

Table 2. Hypothesis Testing Concept Mastery of State Senior High School Students in Pekanbaru City

\begin{tabular}{|c|c|c|c|c|c|}
\hline Senior high school & t-count & t-table & Sig value & $\alpha$ value & Conclusion \\
\hline $\mathrm{W}$ & 03.12 & 1.687 & 0.004 & & $\mathrm{H}_{1}$ is accepted \\
\hline $\mathrm{X}$ & 06.27 & 1.692 & 0.000 & & $\mathrm{H}_{1}$ is accepted \\
\hline $\mathrm{Y}$ & 11.83 & 1.687 & 0.000 & 0.05 & $\mathrm{H}_{1}$ is accepted \\
\hline $\mathrm{Z}$ & 03.40 & 1.695 & 0.002 & & $\mathrm{H}_{1}$ is accepted \\
\hline State senior & 10.67 & 1.656 & 0.000 & & $\mathrm{H}_{1}$ is accepted \\
\hline
\end{tabular}




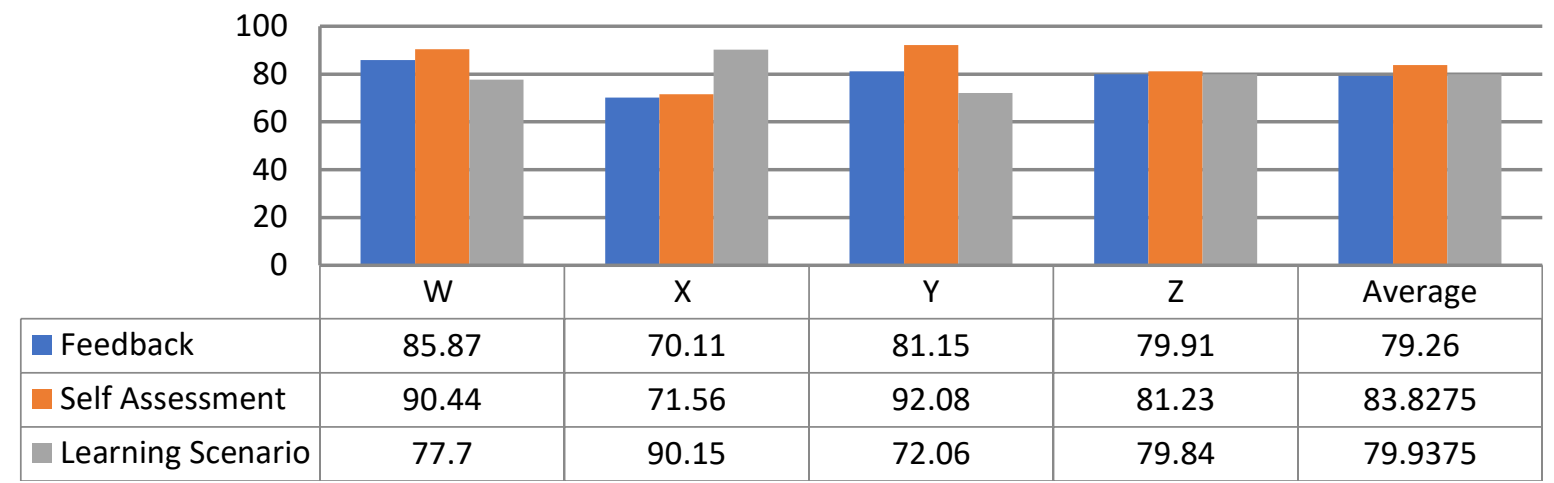

Figure 2. Result student responses to questionnaire about of use the portfolio assessment

Through portfolio assessment, students are trained in developing conceptual knowledge about the relationship between structure, organ function, and processes and disorders/ diseases that can occur in the excretory system in humans. Portfolio assignments also train students to have a sense of responsibility, and instill awareness to improve their abilities (Patni et al., 2018). Portfolio assessment facilitates teachers in accessing the development of students' conceptual understanding, in addition, knowing the abilities students have will be motivated to learn so that it will instill an understanding in students. Furthermore, how much influence the assessment component has on students' mastery of concepts is informed through Figure 3.

Based on Figure 3, it is known that on average, the portfolio assessment components in the form of feedback and self-assessment have the same impact on concept mastery with a score of 59.71\%. Students think that examples of feedback given to students can be seen in Figure 4.
Whereas students who think that written feedback contributes to mastery is greater than self-assessment (18.79\%) than students who think that self-assessment provides a greater impact than written feedback. Some of the assignments that are used as portfolio assignments are essays and practicum reports. Students who have submitted their assignments are given the opportunity to improve their assignments after being given feedback by the teacher. Based on the research results, it shows that the value of the assignments given has a big increase after being given feedback and the opportunity to improve it. Providing feedback and opportunities to correct student mistakes in their assignments is one example of a teacher in creating a positive environment in authentic assessment (Subban \& Round, 2015). From this research shows that all feedback in the form of self-assessment and written feedback either individually or collectively has a positive effect on the students' mastery of concepts.

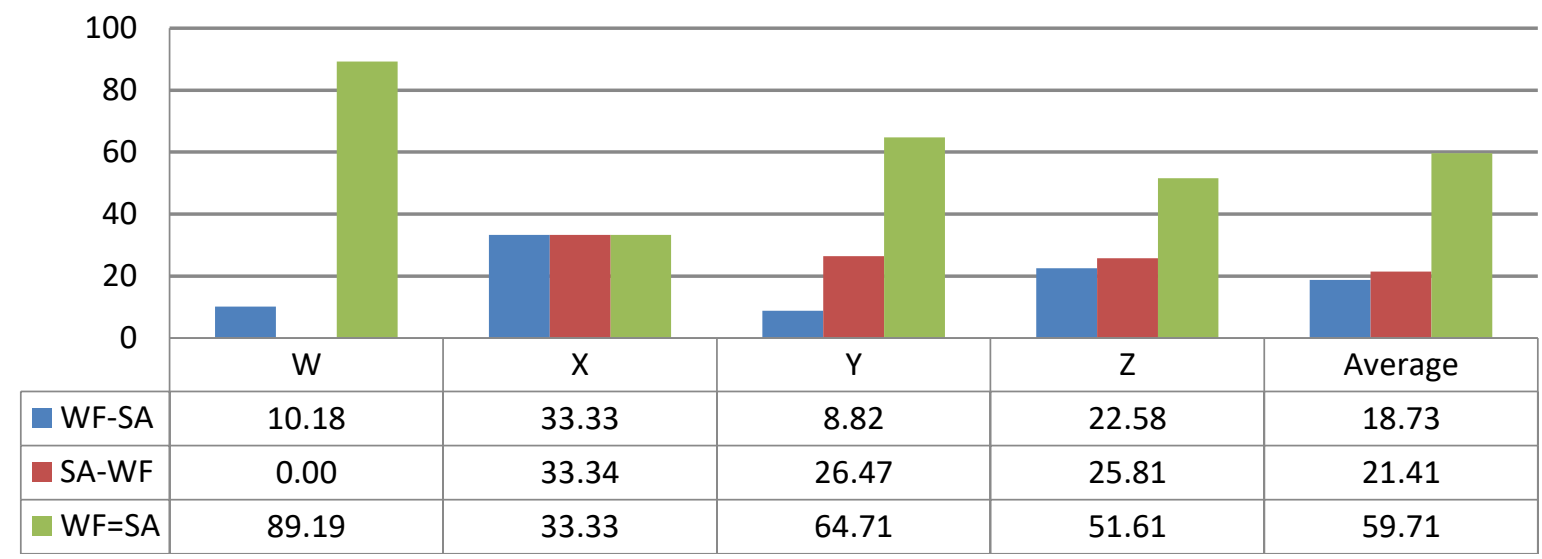

Figure 3. Assessment component that has an influence on students' mastery of concepts (WF: Writing feedback; SA: Self-assessment) 


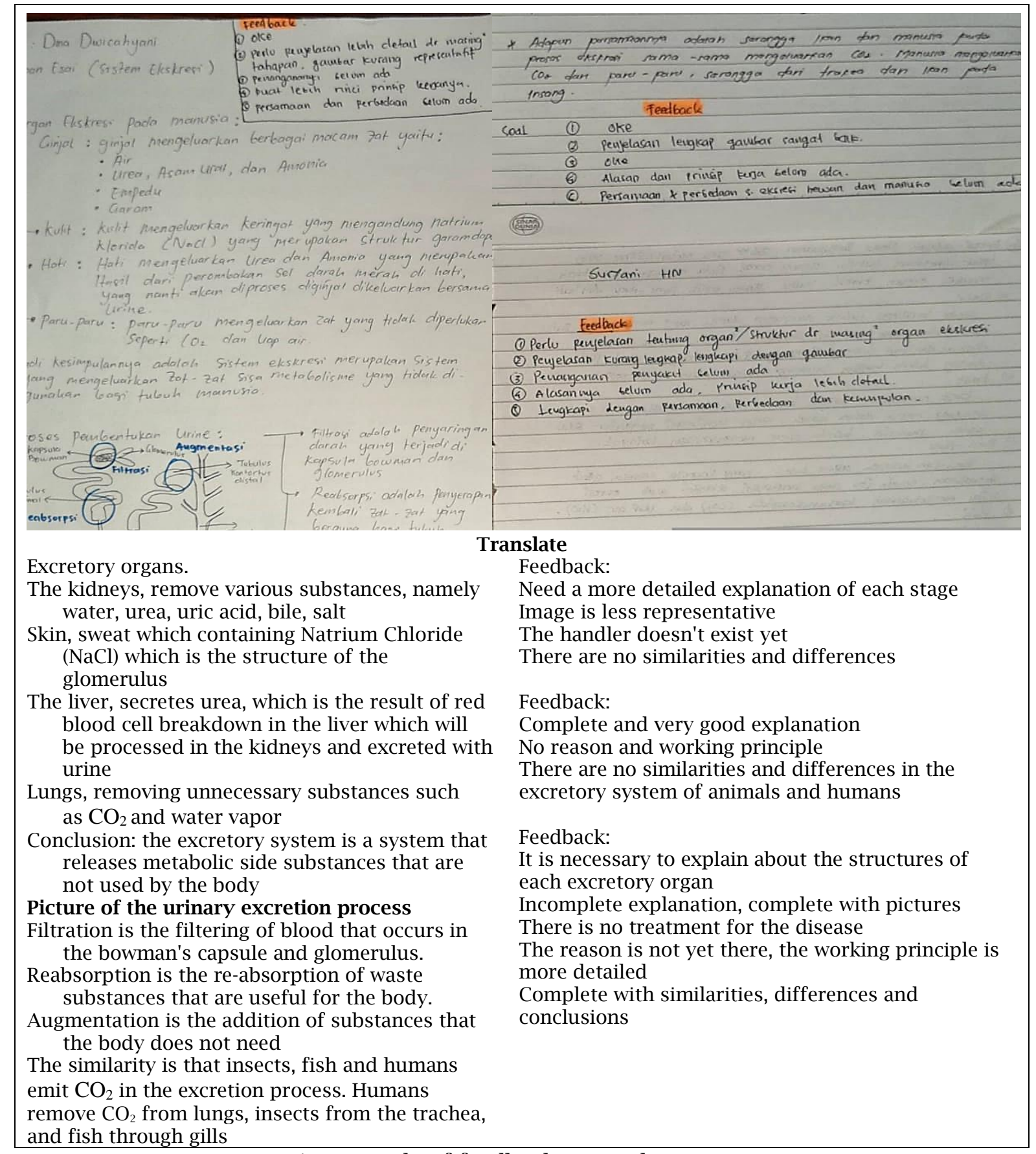

Figure 4. Example of feedback on student assignments

Student responses to the learning scenario are seen through four indicators, namely: student enjoy learning, student portfolio assessment, they are obstacles during learning and the task given are useful (Figure 5).

Based on Figure 5, it can be seen that $90.27 \%$ of students enjoyed the learning that was carried out and all students thought that the assignment given was beneficial for increasing their knowledge. The key element in learning is to create and form positive attitudes and perceptions
(Abedl \& Alrababah, 2017) which in turn will affect student learning abilities. The results of this student response also show that the assignment given in the portfolio assessment provides benefits for students so that it affects students' understanding of concepts. Classwork is very important and useful for students, and when students have a positive attitude towards a given class assignment, the task will be accomplished well (Abedl \& Alrababah, 2017). In this study, the teacher not only gave assignments independently, but each 
assignment that had been done by students would then be subject to feedback.

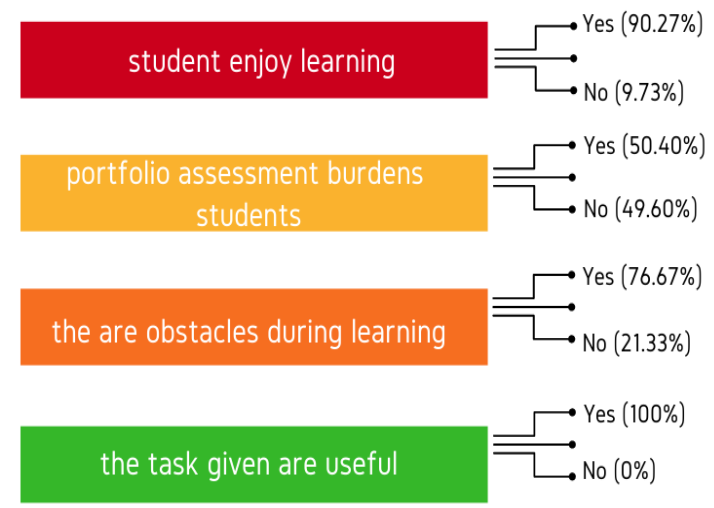

Figure 5.Student response after implementing the portfolio assessment

Based on interviews with students, giving feedback on assignments both on essays and practicum reports helps them understand the mistakes they made and can correct these mistakes and not repeat the same mistakes at a later date. The results showed that the use of portfolio assessment was able to improve learning outcomes and better attitudes. In addition, students also think that portfolio assessment makes learning more meaningful (Cakani et al., 2010). In line with that research by Gunay and OganBekiroglu (2014) explains that portfolio assessment not only provides clues to students 'cognitive development but can also improve students' understanding abilities because portfolio assessment includes self-assessment, self-reflection, and feedback that facilitate student learning activities. However, the assignments given should be considered so that students are not bored and burdensome (Kılıç \& Mathews-Aydınlı, 2009; Tiwari \& Tang, 2003).

\section{Conclusion}

Based on the research that has been done, it can be concluded that the mastery of the concepts of SMAN students in Pekanbaru City increased in the medium category with an average n-gain of 0.55 . The use of the dimension of learning approach with portfolio assessment has a very significant effect on the improvement of students' mastery of concepts with an average t-count of 10.67 and an increase in concept mastery exceeding 0.31 . In addition, students also gave good responses to the use of the dimension of learning approach with portfolio assessment as evidenced by $90.27 \%$ enjoying the learning process. Further research can be carried out for deepening of research on the effects of the portfolio in other aspects besides concept mastery. In addition, other studies can use the control class to apply the traditional methods and to use the factor rotation technique.

\section{References}

Abdulrab, A. H. M., \& SridharSingh, Y. N. (2012). Impact of Marzano's dimensions of learning model on students' science achievement. PARIPEX - Indian Journal of Research, 1(11), 34-35. https://www.worldwidejournals.co $\mathrm{m} /$ paripex/recent_issues_pdf/201 2/November/impact-of-marzanosdimensions-of-learning-model-onstudents-scienceachievement_November_2012_597 9500155_9701271.pdf

Abedl, F. E., \& Alrababah, R. (2017). The effectiveness of Marzano's dimensions of learning model in the tenth grade students acquisition of scientific concepts in science and the development of critical thinking skills and their attitude towards science. British Journal of Education, 5(1), 76-84. http://www.eajournals.org/wpcontent/uploads/The-

Effectiveness-of-MarzanosDimensions-of-Learning-Model-inthe-Tenth-Grade-StudentsAcquisition.pdf

Amua-Sekyi, E. T. (2016). Assessment, student learning and classroom practice: A review. Journal of Education and Practice, 7(21), 1-6. https://files.eric.ed.gov/fulltext/EJ 1109385.pdf

Artini, N. M., Marhaeni, A. A. I. N., \& Dantes, N. (2014). Pengaruh implementasi asesmen portofolio terhadap kemampuan menulis dalam bahasa Inggris dengan pengendalian selfefficacy pada siswa kelas XII IPA SMA Negeri 1 Banjarangkan. Jurnal Penelitian Dan Evaluasi Pendidikan Indonesia, 4(1). https://ejournal- 
pasca.undiksha.ac.id/index.php/ju rnal_ep/article/view/1227

Barton, C., \& Collins, A. (1997). Portfolio assessment: A handbook for educators. Dale Seymour Publications.

Baumfalk, B., Bhattacharya, D., Vo, T., Forbes, C., Zangori, L., \& Schwarz, C. (2019). Impact of model-based science curriculum and instruction on elementary students' explanations for the hydrosphere. Journal of Research in Science Teaching, 56(5), 570-597. https://doi.org/10.1002/tea.21514

Birgin, O., \& Adnan, B. (2007). The use of portfolio to assess student's performance. Journal of Turkish Science Education, 4(2), 75-90. https://www.tused.org/index.php/ tused/article/view/673

Black, P., \& Wiliam, D. (2010). Inside the black box: Raising standards through classroom assessment. Phi Delta Kappan, 92(1), 81-90. https://doi.org/10.1177/00317217 1009200119

Cakani, M., Mihladiz, G., \& Göçmen-Taşkin, B. (2010). How portfolio use affects students' learning and their attitudes toward 6 th grade science lesson. Internasional Journal Educational Sciences, 2(2), 362 377. https://iojes.net/index.jsp? $\bmod =$ tammetin\&makaleadi=\&maka leurl=IOJES_268.pdf\&key $=41360$

Cherif, A. H., Roze, M., \& Gialamas, S. (2016). The free classroom creative assignment: Leveraging student strengths to enhance learning. The International Schools Journal, 35(2), 57-66. https://search.proquest. com/openview/7d24d1c046b92ffb 98f96687a179f50c/1?pq-origsite $=$ gscholar $\& \mathrm{cbl}=2029238$

Cowie, B., \& Bell, B. (1999). A model of formative assessment in science education. Assessment in Education: Principles, Policy \& Practice, 6(1), 101-116. https://doi.org/10.1080 /09695949993026

Doğru, M. S., \& Özsevgeç, L. C. (2018). Biology subjects which the teacher candidates have difficulties in learning and leading reasons. European Journal of Education Studies, 5(1), 221-232. https://oapub.org/edu/index.php/ ejes/article/view/2059

Fourie, I., \& Van Niekerk, D. (2001). Followup on the use of portfolio assessment for a module in research information skills: An analysis of its value. Education for Information, 19(2), 107-126. https://content.iospress.com/articl es/education-for-information/ efi00712

Frohbeiter, G., Greenwald, E., Stecher, B., \& Schwartz, H. (2011). Knowing and doing: What teachers learn from formative assessment and how they use information. https://files.eric. ed.gov/fulltext/ED522825.pdf

Gunay, A., \& Ogan-Bekiroglu, F. (2014). Impact of portfolio assessment on physics students' outcomes: Examination of learning and attitude. EURASIA Journal of Mathematics, Science and Technology Education, 10(6), 667680. https://doi.org/10.12973/ eurasia.2014.1227a

Hake, R. R. (1999). Analyzing change/gain scores. https://www.physics. indiana.edu/ sdi/AnalyzingChang e-Gain.pdf

Haruna, A., Ramlawati, R., \& Auliah, A. (2018). The effect of using assessment portfolio through STAD type of cooperative learning toward student's achivement of class X MIA SMA Negeri 1 Tellu Siattinge Kabupaten Bone (Studi pada materi pokok struktur atom dan tabel periodik). Chemica: Jurnal Ilmiah Kimia Dan Pendidikan Kimia, 19(1), 8-19. https://doi.org/10.35580/chemica. v19i1.6634

Hines, M. E., Catalana, S. M., \& Anderson, B. N. (2019). When learning sinks in: Using the incubation model of teaching to guide students through the creative thinking process. Gifted Child Today, 42(1), 36-45. https://doi.org/10.1177/10762175 18804858

Holmes, P. (2002). Teaching, learning and assessment: Complementary or conflicting categories for school statistics. Proceedings of the Sixth International Conference on Teaching Statistics. https://iase- 
web.org/documents/papers/icots6 /04_ho.pdf

Javed, T. (2012). A study of effectiveness of dimensions of learning model for science teaching at elementary level [National University of Modern Languages Islamabad]. http://173.208.131.244:9060/xmlu i/handle/123456789/6508

Joshi, M. K., Gupta, P., \& Singh, T. (2015). Portfolio-based learning and assessment. Indian Pediatrics, 52(3), 231-235. https://doi.org/10. 1007/s13312-015-0613-2

Kippers, W. B., Wolterinck, C. H. D., Schildkamp, K., Poortman, C. L., \& Visscher, A. J. (2018). Teachers' views on the use of assessment for learning and data-based decision making in classroom practice. Teaching and Teacher Education, 75, 199-213. https://doi.org/10. 1016/j.tate.2018.06.015

Kılıç, E., \& Mathews-Aydınlı, J. (2009). Portfolio implementation at Turkish university preparatory schools, and teachers' perceptions of portfolios and problems experienced with portfolio use [Bilkent University]. In Thesis. http://hdl.handle.net/11693/29993

Ling, M. K. (2016). The use of academic portfolio in the learning and assessment of physics students from a Singapore private college. International Journal of Assessment Tools in Education, 3(2), 151-161. https://doi.org/10.21449/ijate.245 199

Marzano, R. J. (1992). A different kind of classroom: Teaching with dimention of learning. Association for Supervision and Curriculum Development.

Maxwell, J. A. (2004). Causal explanation, qualitative research, and scientific inquiry in education. Educational Researcher, 33(2), 3-11. https://doi.org/10.3102/0013189X 033002003

Mhlauli, M. B., \& Kgosidialwa, K. (2016). The use of a portfolio to enhance authentic assessment among inservice student-teachers' in social studies education at the University of Botswana. Journal of Education and Human Development, 5(3), 84-
96. https://doi.org/10.15640/jehd. v5n3a10

Mogonea, F. (2015). Portfolio-tool for (Self) evaluation of students-future teachers. Procedia - Social and Behavioral Sciences, 180, 860-864. https://doi.org/10.1016/j.sbspro.2 015.02 .227

Mokhtaria, L. (2015). The use of portfolio as an assessment tool. International Journal of Scientific \& Technology Research, 4(07), 170-172. https://www.ijstr.org/final-print/ july2015/The-Use-Of-Portfolio-AsAn-Assessment-Tool.pdf

Olson, M. W. (1991). Portfolios: Education tools. Reading Psychology, 12(1), 73-80.

Patni, L. D. P., Parwati, N. N., \& Suharta, I. G. P. (2018). Peningkatan pemahaman konsep matematika siswa melalui penerapan model pembelajaran AIR disertai penilaian portofolio. Jurnal Pendidikan Dan Pembelajaran Matematika Indonesia, $\quad 7(1), \quad 22-32$. https://doi.org/10.23887/jppm.v7i 1.2810

Paulson, F. L., Paulson, P. R., \& Meyer, C. A. (1991). What makes a portfolio a portfolio. Educational Leadership, 48(5), 60-63. https://web.stanford. edu/dept/SUSE/projects/ireport/a rticles/e-portfolio/what makes a portfolio a portfolio.pdf

Popham, W. J. (2000). Modern educational measurement. Practical guidelines for educational leaders (3rd ed.). Pearson Education.

Ramlawati, R., Liliasari, L., Martoprawiro, M. A., \& Wulan, A. R. (2014). The effect of electronic portfolio assessment model to increase of students' generic science skills in practical inorganic chemistry. Journal of Education and Learning (EduLearn), 8(3), 179-186. https://doi.org/10.11591/edulearn .v8i3.260

Retnawati, H., Hadi, S., \& Nugraha, A. C. (2016). Vocational high school teachers' difficulties in implementing the assessment in curriculum 2013 in Yogyakarta province of Indonesia. International Journal of Instruction, $9(1)$, 33-48. https://doi.org/ 10.12973/iji.2016.914a 
Ring, G., \& Ramirez, B. (2012). Implementing ePortfolios for the assessment of general education competencies. International Journal of EPortfolio, 2(1), 87-97. http://www.theijep.com/pdf/IJEP6 2.pdf

Rizavega, I. H. (2018). Authentic assessment based on curriculum 2013 carried by EFL teacher. Jurnal Profesi Keguruan, 4(2), 142-149. https://journal.unnes.ac.id/nju/in dex.php/jpk/article/view/17375

Rowais, A. S. Al. (2019). Effectiveness of Marzano's dimensions of learning model in the development of creative thinking skills among Saudi foundation year students. World Journal of Education, 9(4), 49-64. https://doi.org/10.5430/ wje.v9n4p49

Roy, P. (2016). Creativity and science education for the gifted: Insights from psychology. In K. S. Taber \& M. Sumida (Eds.), International Perspectives on Science Education for the Gifted: Key issues and challenges. Routledge.

Rustaman, N. Y. (2010). Penilaian portofolio. Universitas Pendidikan Indonesia.

Sahu, S., Soudarssanane, M., Roy, G., Premrajan, K., \& Sarkar, S. (2008). Use of portfolio-based learning and assessment in community-based field curriculum. Indian Journal of Community Medicine, 33(2), 81-84. https://doi.org/10.4103/09700218.40873

Saragih, L. E., \& Tarigan, R. (2016). Perbedaan hasil belajar siswa dengan menggunakan model pembelajaran kooperatif script dan problem based instruction pada materi pokok sistem ekskresi manusia. Jurnal Pelita Pendidikan, 4(2), 148-152. https://jurnal. unimed.ac.id/2012/index.php/peli ta/article/view/4057

Shepard, L. A. (2005). Formative assessment: Caveat emptor. In ETS Invitational Conference The Future of Assessment: Shaping Teaching and Learning. Lawrence Erlbaum Associates, Inc.
Stiggins, R. J. (1994). Student-centered classroom assessment. Macmillan College Publishing.

Subban, P. K., \& Round, P. (2015). Differentiated instruction at work. Reinforcing the art of classroom observation through the creation of a checklist for beginning and preservice teachers. Australian Journal of Teacher Education, 40(5), 117131. https://doi.org/10.14221/ajte $.2015 \mathrm{v} 40 \mathrm{n} 5.7$

Sugiyono. (2015). Statistika untuk penelitian.

Sulistyo, T., Eltris, K. P. N., Mafulah, S., Budianto, S., Saiful, S., \& Heriyawati, D. F. (2020). Portfolio assessment: Learning outcomes and students' attitudes. Studies in English Language and Education, 7(1), 141153. https://doi.org/10.24815/ siele.v7i1.15169

Sunarto, S., \& Riduwan, R. (2013). Pengantar statistika untuk penelitian pendidikan, sosial, komunikasi, ekonomi, dan bisnis. CV Alfabeta.

Supovitz, J. (2012). Getting at student understanding--The key to teachers' use of test data. Teachers College Record, 114(11). http://www.tcrecord.org/Content.a sp?ContentId $=16804$

Surapranata, S., \& Hatta, M. (2006). Penilaian portofolio: Implementasi kurikulum 2004. Remaja Rosdakarya.

Tawiland, M., \& Amin, B. D. (2013). Portfolio-based physics learning model to improve critical thinking skills. International Journal of Education and Research, 1(9), 1-8. http://www.ijern.com/journal/Sep tember-2013/43.pdf

Tiwari, A., \& Tang, C. (2003). From process to outcome: the effect of portfolio assessment on student learning. Nurse Education Today, 23(4), 269277. https://doi.org/10.1016/S02 60-6917(03)00012-1

Trumbull, E., \& Lash, A. (2013). Understanding formative assessment: insights from learning theory and measurement theory. WestEd. 
https://www.wested.org/online_pu bs/resource1307.pdf

Van der Kleij, F. M., Vermeulen, J. A., Schildkamp, K., \& Eggen, T. J. H. M. (2015). Integrating data-based decision making, Assessment for Learning and diagnostic testing in formative assessment. Assessment in Education: Principles, Policy \& Practice, 22(3), 324-343. https://doi.org/10.1080/0969594X .2014 .999024

Wehmeyer, M. L., Shogren, K. A., Palmer, S. B., Williams-Diehm, K. L., Little, T. D., \& Boulton, A. (2012). The impact of the self-determined learning model of instruction on student self-determination. Exceptional Children, 78(2), 135-153. https://doi.org/10.1177/00144029 1207800201

Wiliam, D. (2011). What is assessment for learning? Studies in Educational Evaluation, 37(1), 3-14. https://doi.org/10.1016/j.stueduc. 2011.03.001

Zulfikar, T. (2018). The making of Indonesian education: An overview on empowering Indonesian teachers. Journal of Indonesian Social Sciences and Humanities, 2, 13-39. https://doi.org/10.14203/ jissh.v2i0.19 